\title{
Aurelia Kotriewicz
}

Uniwersytet Pedagogiczny im. KEN w Krakowie

iD

ORCID https://orcid.org/0000-0003-4210-4257

\section{Wiktor Woroszylski, Wyktady o literaturze rosyjskiej (Uniwersytet Latający 1978-1979), przygotował do druku Piotr Mitzner, Wydawnictwo Naukowe UKSW, Warszawa 2020}

Jesienią 1977 roku w kręgach opozycyjnych wobec ówczesnej władzy powstał Uniwersytet Latający - fenomen na skalę europejską, działający aż do lat 80. pod patronatem Towarzystwa Kursów Naukowych. W ramach Uniwersytetu, który swoją nazwą nawiązywał do najbardziej szczytnych polskich tradycji samokształceniowych w okresie zaborów, wykładali najwybitniejsi przedstawiciele opozycji demokratycznej owych lat, wśród których wymienić wypada Stefana Amsterdamskiego, Jacka Kuronia, Władysława Bartoszewskiego czy Jerzego Jedlickiego. W planach Uniwersytetu Latającego, działającego poza cenzurą i oficjalnym życiem kulturalnym, znalazł się cykl kilkunastu wykładów, które w latach 1978-1979 wygłosił w swoim prywatnym mieszkaniu na warszawskim Żoliborzu Wiktor Woroszylski - poeta, pisarz, tłumacz, wytrawny znawca kultury i literatury rosyjskiej, działacz kulturalny i opozycjonista. Wykłady te, gromadzące zwykle do około dwudziestu słuchaczy, kończące się ciekawymi dyskusjami, miały przybliżać całkowicie nieznane ówczesnemu polskiemu odbiorcy rosyjskie zjawiska kulturowe i literackie, poruszane w nich 
były najważniejsze problemy decydujące o tożsamości kultury rosyjskiej.

"Jestem ofiarą literatury rosyjskiej" roszylski $\mathrm{w}$ wywiadzie $\mathrm{z}$ Tatianą Bek, mając na względzie doświadczenia osobiste: po 1939 roku Grodno, w którym się urodził i mieszkał do 1945 roku, przestało być miastem polskim. Żywioł języka rosyjskiego, rozbrzmiewającego na ulicach, w pieśniach, w wierszach i w filmach, zawładnął wyobraźnią przyszłego autora takich książek jak Kto zabił Puszkina?, Życie Majakowskiego, Sny pod śniegiem i wielu innych. W ostatnim, XV wykładzie O Puszkinie - Woroszylski rozwinie wątek losu poety, wpisujący się w charakterystyczny dla kultury rosyjskiej model losów pisarza, rozumiany jako trwale obecne w świadomości twórców rosyjskich, poczynając od wieku XIX poczucie zagrożenia, zamknięcia w klatce, obcości, niedostosowania, oporu wobec władzy i niespełnionych snów o wolności. Tragiczny los Aleksandra Puszkina realizuje się więc w życiu i twórczości zarówno Michaiła Lermontowa i Aleksandra Poleżajewa, jak i Mariny Cwietajewej, Anny Achmatowej, Włodzimierza Majakowskiego, Osipa Mandelsztama i Tycjana Tabidze. To przekleństwo poezji rosyjskiej paradoksalnie jednak, jak stwierdza Woroszylski, jest być może jej wielkim błogosławieństwem, „bo może tylko w polu takich losów rodzi się wielkie napięcie poezji” (s. 331).

W prekursorskim, polemicznym wobec ówczesnego literaturoznawstwa radzieckiego wykładzie Włodzimierz Sołowjow i nowoczesność krytyk definiuje nowoczesną sztukę jako tę, która odpowiada na zmiany cywilizacyjne i postępującą alienację społeczną, kreśli jej historię, dostrzegając jej początki na przełomie XIX i XX wieku w nurcie symbolizmu, lecz przede wszystkim w latach późniejszych, kiedy do głosu doszli twórcy spod znaku akmeizmu, futuryzmu i imażynizmu. Artystami zasługującymi na szczególną uwagę w tym względzie są dla Woroszylskiego Siergiej Jesienin,

${ }^{1}$ W. Woroszylski, Wykłady o literaturze rosyjskiej (Uniwersytet Latający 19781979), przygotował do druku P. Mitzner, Wydawnictwo Naukowe UKSW, Warszawa 2020, s. 370. Dalej cytuję według tego wydania, w nawiasie podaję numer strony. 
Nikołaj Klujew i Włodzimierz Majakowski, „samotnicy, osaczeni przez byt" (s. 53).

Woroszylski prezentuje w swoich wykładach bardzo osobiste i odkrywcze jak na lata 70. poprzedniego stulecia spojrzenie na ówczesną literaturę rosyjską. Jest ona dla niego „czymś uderzająco odrębnym od wszystkich pozostałych literatur europejskich” (s. 18). Jej dawny i współczesny obraz, który przedstawia w wykładach, jawi się jako swojego rodzaju barometr napięć społecznych i politycznych, a także przeobrażeń światopoglądowych. Nade wszystko jednak jest ta literatura „sposobem istnienia inteligencji rosyjskiej, sposobem ekspresji jej obolałego sumienia, i ekspiacji, i oczyszczenia" (s. 305). Jeden z interesujących wykładów poświęcił Woroszylski właśnie rozważaniom na temat inteligencji rosyjskiej i jej odwiecznemu poczuciu społecznego obowiązku, ale także i winy wobec ludu rosyjskiego, i - co z tym się wiąże — różnym, spolaryzowanym postrzeganiem rewolucji rosyjskiej. Odzwierciedleniem tych dylematów są literatura i eseistyka, by wymienić choćby Mowę o Puszkinie Fiodora Dostojewskiego, Myśli nie na czasie Maksyma Gorkiego czy poemat Dwunastu Aleksandra Błoka.

Szeroką panoramę rosyjskiego życia kulturowo-literackiego po przewrocie październikowym 1917 roku przedstawia badacz w wykładach Życie literackie w Rosji w latach 20. i 30. Proletkult oraz O utopiach. Dążenie do stworzenia nowej sztuki kolektywistycznej, odzwierciedlające się choćby w utopii Aleksego Gastiewa, zaowocowało w latach 30. podporządkowaniem kultury dyrektywom partii i zapoczątkowało jej monistyczny charakter. Przestrogą miała być antyutopia $M y$ Jewgienija Zamiatina, prekursorska wobec wizji totalitarnego państwa, zaprezentowanej potem w powieści 1984 George'a Orwella.

Przekorny tytuł jednego z wykładów O degrengoladzie literatury i próbach jej przezwyciężenia traktuje o tzw. drugim obiegu literatury, który był wyzwaniem i rękawicą rzuconą władzy. Właśnie samizdat i tamizdat, drukujące takich autorów jak Warłam Szałamow, Aleksander Sołżenicyn, Gieorgij Władimow czy Lidia Czukowska, przełamywały milczenie na temat opresji systemu komunistycznego, niewolniczej pracy więźniów GUŁagu, terroru i czystek lat 30. 
To właśnie tam prowadzono polemikę z obowiązującą przez wiele dziesiątków lat jedyną słuszną metodą artystyczną, jaką był socrealizm. Jak się wkrótce okazało, Woroszylski już wtedy, w latach 70., przewidział, że wkrótce nastąpi integracja dwóch wykluczających się obiegów: oficjalnego i alternatywnego.

Świat koncentracyjny $\mathrm{w}$ literaturze rosyjskiej, rozpatrywany w perspektywie historycznej, stał się tematem odrębnego wykładu, w którym badacz analizował takie książki jak Kanał Białomorsko-Bałtycki im. Stalina pod redakcją Maksyma Gorkiego, będący apoteozą pracy niewolniczej więźniów w imię „pieriekowki” ich dusz, poemat Requiem Anny Achmatowej, powieść Sofia Pietrowna Lidii Czukowskiej i sztukę Elżbieta Bam Daniiła Charmsa. Rozważania swoje snuje Woroszylski wokół stosowanych przez twórców zabiegów, ukazujących koszmar totalitarnego świata: ironii, groteski i absurdu, rozumianych jako znak oporu wobec totalitarnej, zakłamanej rzeczywistości. Wielce zajmujące i prekursorskie są uwagi Woroszylskiego na temat absurdalnej i demonicznej wizji świata, zaproponowanej przez rosyjskich artystów. Ich dzieła nie są tu postrzegane li tylko jako diagnoza rzeczywistości „na opak”, lecz jako bunt i odwet na niej, wyłom w nauczycielskiej tradycji literatury rosyjskiej. Rozważania swoje oparł Woroszylski głównie na takich powieściach, wariantach demonicznej wizji rzeczywistości w literaturze rosyjskiej, jak między innymi Nos Mikołaja Gogola, Mały bies Fiodora Sołoguba, utworach Bułhakowa, z uwzględnieniem przede wszystkim powieści Mistrz i Małgorzata, oraz twórczości leningradzkiego ugrupowania OBERIU, działającego w latach 20. Niedorzeczność, absurd, gra i karnawalizacja, powołane przez rzeczywistość zgoła nieliteracką, służą wyrażeniu „realnej niedorzeczności zautomatyzowanej egzystencji” (s. 213), ukrywając śmiertelne przerażenie i złowieszcze przeczucia oberiutów. Nowatorstwo formalne ich dzieł, twierdzi badacz, wyprzedza osiągnięcia późniejszego europejskiego teatru absurdu.

Kilka swoich wykładów poświęcił Woroszylski takim fenomenom kultury rosyjskiej jak słowianofilstwo, rozpatrywane na szerokim tle historycznym, eurazjanizm i panmongolizm. Ten ostatni krytyk dzieli na „stary”, reprezentowany przez Włodzimierza So- 
łowjowa, głoszący powstanie społeczeństwa bogoczłowieczego pod egidą Wschodu, który w przeciwieństwie do Zachodu zachował pierwiastek boski, i „nowy”, łączący w sobie elementy azjatyckie i rosyjskie, kulturę azjatyckich przodków z kulturą rosyjską. Badacz analizuje te zjawiska przez pryzmat ich literackich odzwierciedleń w twórczości Aleksandra Błoka, Andrieja Biełego, Giennadija Ajgiego, Bełły Achmaduliny, Czyngiza Ajtmatowa.

Wykłady Wiktora Woroszylskiego do dzisiaj nie straciły na aktualności. Dają one ciekawy, niejednoznaczny i zniuansowany, choć bardzo subiektywny, obraz kultury i literatury rosyjskiej, obejmujący kwestie spóźnionych debiutów, zapomnianych twórców i ich skomplikowanych relacji z władzą. Wykłady są również portretem samego Woroszylskiego, który przez taki właśnie wybór tematów dał wyraz swoim osobistym fascynacjom, które w latach późniejszych znalazły odzwierciedlenie w wielu jego książkach. 